\title{
Phosphorus fractions in the vineyard soil of the Serra Gaúcha of Rio Grande do Sul, Brazil
}

\author{
Djalma E. Schmitt ${ }^{1}$, Luciano C. Gatiboni ${ }^{2}$, Eduardo Girotto ${ }^{3}$, Felipe Lorensini ${ }^{4}$, \\ George W. B. Melo 5 \& Gustavo Brunetto ${ }^{6}$
}

\author{
${ }^{1}$ UDESC. Lages, SC. E-mail: djalma.schmitt@gmail.com (Corresponding author) \\ ${ }^{2}$ UDESC. Lages, SC. E-mail: lgatiboni@gmail.com. Grant in productivy supported by CNPq \\ ${ }^{3}$ Instituto Federal de Educação, Ciência e Tecnologia do Rio Grande do Sul. Santa Maria, RS. E-mail:girottosolos@gmail.com \\ ${ }^{4}$ CCR/UFSM. Santa Maria, RS. E-mail: lorensini@hotmail.com. CAPES fellowship \\ ${ }^{5}$ Embrapa Uva e Vinho. Bento Gonçalves, RS. E-mail: george@cnpuv.embrapa.br \\ ${ }^{6}$ CCR/UFSM. Santa Maria, RS. E-mail: brunetto.gustavo@gmail.com
}

\section{Key words:}

phosphorus fertilization

environmental contamination

Vitis vinifera

\begin{abstract}
A B S T R A C T
The study aimed to evaluate the accumulation of $\mathrm{P}$ fractions in a vineyard soil profile with successive applications of phosphate fertilizers. In January 2010 an area was selected of native forest and a vineyard at age 33 with a history of phosphate fertilizer application, in Bento Gonçalves, Rio Grande do Sul state. Soil samples were collected from 0-5, 5-10 and 10-20 cm layers, prepared and submitted to chemical fractionation of P. The excessive application of phosphate fertilizers during 33 years in the vineyard soil increased the levels of organic and inorganic $\mathrm{P}$ until the $20 \mathrm{~cm}$ layer in all $\mathrm{P}$ fractions. The highest levels of $\mathrm{P}$ in the vineyard soil were found mainly in the labile fractions extracted with anion exchange resin and $\mathrm{NaHCO}_{3}$, which indicates high nutrient availability to plants, but also indicates the potential of transfer of solution from soil to surface run-off or percolated through the soil profile, which represents greater potential for contamination of surface and subsurface waters.
\end{abstract}

Palavras-chave:

adubação fosfatada contaminação ambiental Vitis vinifera

\section{Frações de fósforo no solo de vinhedo na Serra Gaúcha do Rio Grande do Sul}

\begin{abstract}
R E S U M O
Objetivou-se, com este trabalho, avaliar o acúmulo de frações de P no perfil de um solo de vinhedo com aplicações sucessivas de fertilizantes fosfatados. Em janeiro de 2010 foram selecionados, em Bento Gonçalves, RS, uma área de mata nativa e um vinhedo com 33 anos de idade e com histórico de aplicação de fertilizantes fosfatados. Amostras de solo foram coletadas camadas nas camadas de 0-5, 5-10 e 10-20 cm, preparadas e submetidas ao fracionamento químico de P. As aplicações excessivas de fertilizantes fosfatados durante 33 anos no solo de vinhedo aumentaram o teor de P orgânico e inorgânico até a camada $20 \mathrm{~cm}$, em todas as frações de P. Os maiores teores de P no solo do vinhedo foram encontrados principalmente na fração lábil extraída pela resina trocadora de ânions e pelo $\mathrm{NaHCO}_{3}$ que pode aumentar a disponibilidade do nutriente para as plantas mas também potencializar sua transferência pela solução escoada na superfície do solo ou percolada no perfil, o que representa maior potencial de contaminação de águas superficiais e subsuperficiais.
\end{abstract}

\section{INTRODUCTION}

Rio Grande do Sul (RS) state has the largest area planted with vines in Brazil with, approximately, 50,000 ha (IBGE, 2011). The Serra Gaucha region, located in the northeast of the state, is the largest wine region of Brazil and the vineyards are typically implanted in Humic Cambisol soil located in uneven topography. In the region, before planting the vines and the need having been established, based on the results of chemical analysis, soils are submitted to the application of lime to correct soil acidity and elevated levels of calcium $(\mathrm{Ca})$ and magnesium $(\mathrm{Mg})$ in the soil, which improves the chemical environment for the growth of roots. Furthermore, correction fertilization is performed with phosphorus $(\mathrm{P})$ and potassium $(\mathrm{K})$ fertilizers to increase the level of nutrients in the soil. After installation of the vineyard and when a need is diagnosed through analysis of plant tissue (leaves) and expected grape yield (CQFS, 2004), new applications of fertilizers like nitrogen (N), P and $\mathrm{K}$ are performed on the soil surface without incorporation, which represents the maintenance fertilization. However, the application of nutrients in correction fertilization, but especially in maintenance fertilization, is not always defined based on technical criteria (analysis of soil and tissue and expected grape yield). Thus, over the years, there may be an accumulation of $\mathrm{P}$ in the surface layers of the soil and saturation of the adsorption sites of the reactive particles (Korboulewsky et al., 2002), which 
can increase nutrient availability to plants, but also maximize its solution transfer from surface run-off to surface waters (Oliveira et al., 2010). The transfer can also occur by percolation through the soil profile, increasing contamination of subsurface waters (Chien et al., 2011) including vineyard soils (Ramos \& Martínez-Casasnova, 2006).

Studies on the accumulation of $\mathrm{P}$ fractions in the soil have been conducted based on the chemical fractionation technique proposed by Hedley et al. (1982). This technique uses chemical extractors that remove, sequentially, inorganic and organic $P$, from the more available to the more stable fractions. With the chemical fractionation of $\mathrm{P}$ it can be observed that in soils with a history of successive applications of phosphate fertilizers, an accumulation of organic and inorganic fractions of soil nutrient in different degrees of binding energy occurs, although the accumulation is usually more pronounced in the labile inorganic fractions, like those accessed with the anion exchange resin (RTA) and $\mathrm{NaHCO}_{3}$ extractors (Gatiboni et al., 2007; Santos et al., 2008; Boschetti et al., 2009; Tokura et al., 2011). In general, $\mathrm{P}$ adsorption applied to the soil occurs initially on the sites that are most avid and of greater bonding strength and subsequently the remaining $\mathrm{P}$ is redistributed in fractions with lower energy (Rheinheimer \& Anghinoni, 2001). Thus, it is expected that the greater the amount of phosphate fertilizers applied over the years, the greater the saturation of sites of higher binding energy and consequently the more bioavailable $\mathrm{P}$ will be. However, most studies on the distribution of soil $\mathrm{P}$ fractions, which allows the report on the amount of nutrients available to plants or potentially transferable, were performed on soils cultivated with annual crops and a historical application of phosphate fertilizers, although in Brazil, studies carried out on soils cultivated with fruit trees, such as the vineyards with successive applications of phosphate fertilizers, are scarce. Those existing were carried out in vineyard soils with sandy texture, low levels of organic matter and oxides, and clearly show that a good part of the $P$ applied through soluble phosphatic fertilizers accumulates in the soil in labile P fractions, especially accessed with RTA (Schmitt, 2012). But studies published so far, evaluating the $\mathrm{P}$ fractions in vineyard soils, with high clay content, average levels of organic matter and high levels of iron oxides, are nonexistent in Brazil.

The study aimed to evaluate the accumulation of $\mathrm{P}$ fractions in the soil profile of a vineyard at age 33 and with successive applications of phosphate fertilizers, in the Serra Gaucha region of RS.

\section{Material and Methods}

The study was carried out in the Soil, Water and Plant Tissue Laboratory of the Department of Agricultural Engineering of the Federal University of Santa Catarina (Universidade Federal de Santa Catarina - UFSC), in Florianópolis, SC, in the south of Brazil, using soil samples of Humic Cambisol soil (Soil Survey Staff, 1999), from native forest and cultivated with vines, located in the city of Bento Gonçalves, Serra Gaucha region of Rio Grande do Sul (RS) state, Brazil. The climate of the region according to the classification proposed by Köppen-Geiger is humid subtropical (Cfb), with mean annual temperature of $17.2^{\circ} \mathrm{C}$ and mean annual rainfall of $1,716 \mathrm{~mm}$. In January 2010 , at the Embrapa Grape and Wine Experimental field in Bento Gonçalves, RS, an area of native forest (latitude $29^{\circ} 9^{\prime} 42,61^{\prime \prime} \mathrm{S}$ and longitude $51^{\circ} 32^{\prime} 17,70^{\prime \prime} \mathrm{W}$ ) with no history of cultivation or application of phosphate fertilizers was selected, and the results were used as a reference, also a vineyard with a history of application, performed after implantation and throughout the years, which represents the maintenance fertilization of approximately $60 \mathrm{~kg} \mathrm{ha}^{-1}$ of $\mathrm{P}_{2} \mathrm{O}_{5}$ in the form, predominantly, of triple superphosphate on the soil surface without incorporation. The vineyard (latitude $29^{\circ} 9^{\prime} 42,69^{\prime \prime} \mathrm{S}$ and longitude $51^{\circ} 31^{\prime} 46^{\prime \prime}$ W) was located in relief with undulating topography, formed by cultivar Isabel, implemented in 1977 (33 years of age in $2010)$, density of 1,429 plants ha-1 $^{-1}(2.2 \times 3.5 \mathrm{~m})$, the conduction system applied was the trellis covering an area of approximately two hectares. On the vineyard soil, before the planting of vines, limestone was applied on the soil surface, followed by incorporation to raise the $\mathrm{pH}$ of the soil to 6.0. Furthermore, 200 $\mathrm{kg} \mathrm{ha}^{-1}$ of $\mathrm{P}_{2} \mathrm{O}_{5}$ as triple superphosphate and $90 \mathrm{~kg} \mathrm{ha}^{-1}$ of $\mathrm{K}_{2} \mathrm{O}$ in the form of potassium chloride was applied. Both fertilizers were applied on the soil surface and incorporated. Over the years, the tree rows of vines were subjected to periodic applications of herbicides for weed control. Whereas between the rows, the spontaneous vegetation composed of Lolium perenne, Paspalum notatum and Trifolium repens, was maintained. Periodically this vegetation was subject to mowing, and its waste materials deposited on the surface of the soil.

In March 2010, 33 years after the implantation of the vineyard, eight trenches $(0.3 \times 0.5 \times 0.5 \mathrm{~m})$ were opened in the vineyard, along seven rows of planted vines, in the crown projection of the plants, where historically phosphate fertilizers were applied to the soil surface over the years. In addition, another eight trenches were opened randomly in the area of native forest adjacent to the vineyard. Then, soil samples were collected in the 0-5, 5-10 and 10-20 cm layers. Soon after, the soil was dried in an oven with forced air circulation at $\pm 45^{\circ} \mathrm{C}$. Subsequently, the soil was ground, passed through a $2 \mathrm{~mm}$ mesh sieve and divided in to three parts. The first part of the soil was submitted for analysis of particle size distribution of soil constituents using pipette method (EMBRAPA, 1997). Furthermore, the $\mathrm{pH}$ values of water (1:1), the levels of exchangeable aluminum (Al), calcium $(\mathrm{Ca})$ and magnesium $(\mathrm{Mg})\left(\mathrm{KCl}\right.$ extractor $\left.1 \mathrm{~mol} \mathrm{~L}^{-1}\right)$ and exchangeable $\mathrm{K}$ and available $\mathrm{P}$ (Mehlich 1 extractor) were determined (Tedesco et al., 1995) (Table 1). The determination of total organic carbon (TOC) was performed following the methodology proposed by EMBRAPA (1997). The amount of iron $(\mathrm{Fe})$ extracted with dithionite-citrate-bicarbonate (DCB) (Mehra \& Jackson, 1960) and ammonium oxalate (Tedesco et al., 1995) was also determined. The values of $\mathrm{H}+\mathrm{Al}$, Cation exchange capacity at $\mathrm{pH} 7.0\left(\mathrm{CEC}_{\mathrm{pH} 7.0}\right)$ and effective cation exchange capacity $\left(\mathrm{CEC}_{\text {effective }}\right)$, the base saturation of $\mathrm{CEC}_{\mathrm{pH}}$ ${ }_{7.0}(\mathrm{~V})$ and the saturation of $\mathrm{CEC}_{\text {effective }}$ by aluminum $(\mathrm{m})$ were calculated by the equations established by CQFS (2004). 
Table 1. Main physical and chemical characteristics in Humic Cambisol soil in a Native forest site near the vineyard with 33 years of age in three depth layer

\begin{tabular}{|c|c|c|c|c|c|c|}
\hline \multirow{3}{*}{ Soil attributes } & \multicolumn{3}{|c|}{ Native forest } & \multicolumn{3}{|c|}{ Vineyard } \\
\hline & $0-5$ & $5-10$ & $10-20$ & $0-5$ & $5-10$ & $10-20$ \\
\hline & \multicolumn{6}{|c|}{$\mathrm{cm}$} \\
\hline Clay $\left(\mathrm{g} \mathrm{kg}^{-1}\right)^{(1)}$ & 126 & 126 & 171 & 135 & 81 & 126 \\
\hline Silt $\left(\mathrm{g} \mathrm{kg}^{-1}\right)^{(1)}$ & 562 & 581 & 568 & 444 & 513 & 493 \\
\hline Sand $\left(\mathrm{g} \mathrm{kg}^{-1}\right)^{(1)}$ & 312 & 293 & 261 & 421 & 406 & 381 \\
\hline TOC $\left(\mathrm{g} \mathrm{kg}^{-1}\right)^{(1)}$ & 25.2 & 27.6 & 13.9 & 25.3 & 26.6 & 16.6 \\
\hline $\mathrm{pH} \mathrm{H}_{2} \mathrm{O}(1: 1)^{(2)}$ & 6.1 & 6.0 & 5.1 & 5.8 & 6.1 & 6.2 \\
\hline Exchangeable $\mathrm{Al}\left(\mathrm{cmol}_{\mathrm{c}} \mathrm{kg}^{-1}\right)^{(3)}$ & 0.0 & 0.0 & 0.3 & 0.0 & 0.0 & 0.0 \\
\hline Exchangeable $\mathrm{Ca}\left(\mathrm{cmol}_{\mathrm{c}} \mathrm{kg}^{-1}\right)^{(3)}$ & 18.3 & 11.2 & 3.5 & 14.9 & 19.5 & 8.0 \\
\hline Exchangeable $\mathrm{Mg}\left(\mathrm{cmol}_{\mathrm{c}} \mathrm{kg}^{-1}\right)^{(3)}$ & 2.2 & 2.5 & 1.3 & 3.6 & 5.1 & 2.2 \\
\hline $\mathrm{H}+\mathrm{Al}\left(\mathrm{cmo}_{\mathrm{c}} \mathrm{kg}^{-1}\right)^{(4)}$ & 2.0 & 2.6 & 3.5 & 3.0 & 2.7 & 2.0 \\
\hline Base saturation $(\%)^{(4)}$ & 91.8 & 84.3 & 58.4 & 86.0 & 90.0 & 84.2 \\
\hline Aluminium saturation (\%) $)^{(4)}$ & 0.0 & 0.0 & 0.0 & 0.0 & 0.0 & 0.0 \\
\hline $\mathrm{CEC}$ effective $\left(\mathrm{cmol}_{\mathrm{c}} \mathrm{kg}^{-1}\right)^{(4)}$ & 21.0 & 14.0 & 5.0 & 18.8 & 24.9 & 10.4 \\
\hline $\mathrm{CEC}_{\mathrm{pH} 7,0}\left(\mathrm{CmOl}_{\mathrm{c}} \mathrm{kg}^{-1}\right)^{(4)}$ & 22.8 & 16.6 & 8.5 & 21.9 & 27.6 & 12.4 \\
\hline $\mathrm{K}$ Exchangeable $\left(\mathrm{mg} \mathrm{kg}^{-1}\right)^{(5)}$ & 170 & 118 & 63 & 134 & 100 & 93 \\
\hline $\mathrm{P}$ available $\left(\mathrm{mg} \mathrm{kg}^{-1}\right)^{(5)}$ & 18.8 & 5.3 & 4.7 & 109.5 & 5100.7 & 35.7 \\
\hline Fe dithionitecitrate-bicarbonate $\left(\mathrm{g} \mathrm{kg}^{1}\right)^{(6)}$ & 71.1 & 77.9 & 78.0 & 74.6 & 71.5 & 77.2 \\
\hline Fe ammonium oxalate $\left(\mathrm{g} \mathrm{kg}^{-1}\right)^{(7)}$ & 6.2 & 6.0 & 6.2 & 7.5 & 8.0 & 8.9 \\
\hline
\end{tabular}

The second part of the soil samples from the native forest and vineyard area were subjected to chemical fractionation of $\mathrm{P}$, according to the methodology proposed by Hedley et al. (1982), with modifications proposed by Condron et al. (1985), briefly outlined as follows: $0.5 \mathrm{~g}$ samples of soil were subjected to sequential extraction with anion exchange resin $\left(\mathrm{Pi}_{\mathrm{RTA}}\right.$ fraction); $\mathrm{NaHCO}_{3} 0.5 \mathrm{~mol} \mathrm{~L}^{-1}\left(\mathrm{Pi}_{\text {hid }}\right.$ and $\mathrm{Po}_{\text {hid }}$ fraction $) \mathrm{NaOH}$ $0.1 \mathrm{~mol} \mathrm{~L}^{-1}\left(\mathrm{Pi}_{\text {hid05 }}\right.$ and $\mathrm{Po}_{\text {hido5 }}$ fraction); $\mathrm{HCl} 1 \mathrm{~mol} \mathrm{~L}^{-1}\left(\mathrm{Pi}_{\mathrm{HCl}}\right.$ fraction) and $\mathrm{NaOH} 0.5 \mathrm{~mol} \mathrm{~L}^{-1}\left(\mathrm{Pi}_{\text {hid05 }}\right.$ and $\mathrm{Po}_{\text {hido5 }}$ fraction). After the extractions, the remaining soil was dried at $50^{\circ} \mathrm{C}$ and digested with $\mathrm{H}_{2} \mathrm{SO}_{4}+\mathrm{H}_{2} \mathrm{O}_{2}+\mathrm{MgCl}_{2}$ (residual $\mathrm{P}$ ) as described by Gatiboni et al. (2007). The inorganic $\mathrm{P}$ of the $\mathrm{NaHCO}_{3}$ and $\mathrm{NaOH}$ alkali extracts was determined by the method proposed by Dick \& Tabatabai (1977). In these alkali extracts, total P was determined by digestion with ammonium persulfate + sulfuric acid in an autoclave, and the organic $\mathrm{P}$ obtained by the difference between total $\mathrm{P}$ and inorganic $\mathrm{P}$. P of the acid extracts was determined according to Murphy \& Riley (1962). The P forms of the fractionation of Hedley et al. (1982) were grouped into geochemical and biological P (Cross \& Schlesinger, 1995). The geochemical $\mathrm{P}$ was obtained by the sum of the inorganic fractions plus residual $\mathrm{P}\left(\mathrm{Pi}_{\mathrm{RTA}}+\mathrm{Pi}_{\text {bic }}+\mathrm{Pi}_{\text {hid }}+\mathrm{Pi}_{\text {hid05 }}+\mathrm{Pi}_{\mathrm{HCl}}+\right.$ residual $\mathrm{P}$ ) and the biological $\mathrm{P}$ by the sum of the organic fractions $\left(\mathrm{Po}_{\text {bic }}+\mathrm{Po}_{\text {hid }}+\mathrm{Po}_{\text {hido5 }}\right)$.

Data of $P$ content in different layers of the same native forest or vineyard soil and the same layer of different native forest or vineyard soils were subjected to variance analysis (SAS,9.1.3) SAS, 2003]. Phosphorus contents were used as dependent, and soil depth and site as independent variables. The results of all analyses were tested for significance by the $\mathrm{F}$ test at $\leq$ 0.05 probability. Multiple comparisons for P contents, where the variance analysis result was statistically significant, were carried out using Tukey's HSD (Tukey's Honestly Significant Difference) test (0.05).

\section{Results AND Discussion}

The inorganic $\mathrm{P}$ extracted with anion exchange resin $\left(\mathrm{Pi}_{\mathrm{RTA}}\right)$ and $\mathrm{NaHCO}_{3}\left(\mathrm{Pi}_{\text {bic }}\right)$ and the organic $\mathrm{P}$ extracted with $\mathrm{NaHCO}_{3}\left(\mathrm{Po}_{\text {bic }}\right)$ are the first extractants used in the chemical fractionation of $\mathrm{P}$ (Hedley et al., 1982). These extractors access labile $\mathrm{P}$ fractions, with low binding energy, and that can contribute actively in the nutrient supply to plants and can also be transferred from soil solution to surface runoff as far as surface water bodies, but also by percolation through the soil profile, increasing contamination of groundwater (Pizzeghello et al., 2011). In the native forest soil, the highest levels of $\mathrm{Pi}_{\mathrm{RTA}}$ were found in the topsoil $(0-5$ and 5-10 cm) (Table 2), decreasing in depth. Whereas in the the vineyard soil at age 33, the highest levels were found in the $0-5 \mathrm{~cm}$ layer. However, in all layers of the vineyard soil, the level of $\mathrm{P}$ extracted with anion exchange resin was greater than that found in the native forest soil.

The highest levels of $\mathrm{Pi}_{\text {bic }}$ in the vineyard soil were found in the $0-5$ and $5-10 \mathrm{~cm}$ layers, but in the native forest soil, the highest levels were found in the $0-5 \mathrm{~cm}$ layer (Table 2). However, the highest levels of $\mathrm{Pi}_{\text {bic }}$, in all layers, were found in the vineyard soil, comparatively to the native forest soil. The highest levels of $\mathrm{Pi}_{\mathrm{RTA}}$ and $\mathrm{Pi}_{\text {bic }}$ in the layers of vineyard soil in relation to the native forest soil, can be attributed to the application of 200 $\mathrm{kg} \mathrm{ha}^{-1}$ of $\mathrm{P}_{2} \mathrm{O}_{5}$ for correction fertilization performed prior to the implantation of the vineyard, but also the application of $60 \mathrm{~kg} \mathrm{ha}^{-1}$ of $\mathrm{P}_{2} \mathrm{O}_{5}$ for maintenance fertilization performed throughout the cycle of plants. It is worth mentioning that if the $P$ level in the soil before the planting of vines in the vineyard was interpreted as very low $\left(<7.0 \mathrm{mg}\right.$ of $\mathrm{P} \mathrm{dm}^{-3}$, considering the mean level of clay $<20 \%$ ) in the $0-20 \mathrm{~cm}$ layer (CQFS, 2004), the maximum recommended dose would be $150 \mathrm{~kg} \mathrm{ha}^{-1}$ of $\mathrm{P}_{2} \mathrm{O}_{5}$ to increase the $\mathrm{P}$ level in the soil up to the level of sufficiency that

Table 2. Resin inorganic $\mathrm{P}\left(\mathrm{Pi}_{\text {RTA }}\right), \mathrm{NaHCO}_{3}$ inorganic $\mathrm{P}$ $\left(\mathrm{Pi}_{\text {bic }}\right)$ and $\mathrm{NaHCO}_{3}$ organic $\mathrm{P}\left(\mathrm{Po}_{\text {bic }}\right)$ fractions in Humic Cambisol soil in a native forest near the vineyard with 33 years of age in three depth layer

\begin{tabular}{|c|c|c|c|}
\hline \multirow{2}{*}{$P$ fraction } & Depth layer & Forest native & Vineyard \\
\hline & cm & \multicolumn{2}{|c|}{$\mathrm{mg} \mathrm{kg}^{-1}$} \\
\hline \multirow{4}{*}{$\mathrm{Pi}_{\text {RTA }}$} & $0-5$ & $9.6 \mathrm{aB}^{(1)}$ & 35.4 aA \\
\hline & $5-10$ & $7.9 \mathrm{aB}$ & 29.5 bA \\
\hline & $10-20$ & $1.5 \mathrm{bB}$ & $9.3 \mathrm{cA}$ \\
\hline & CV \% & \multicolumn{2}{|c|}{12.44} \\
\hline \multirow{4}{*}{$\mathrm{Pi}_{\text {bic }}$} & $0-5$ & $21.8 \mathrm{aB}$ & $44.2 \mathrm{aA}$ \\
\hline & $5-10$ & $6.2 \mathrm{bB}$ & $43.8 \mathrm{aA}$ \\
\hline & $10-20$ & $6.0 \mathrm{bB}$ & $16.1 \mathrm{bA}$ \\
\hline & CV \% & \multicolumn{2}{|c|}{4.69} \\
\hline \multirow{4}{*}{$\mathrm{Po}_{\text {bic }}$} & $0-5$ & $10.1 \mathrm{aB}$ & $28.3 \mathrm{aA}$ \\
\hline & $5-10$ & $5.1 \mathrm{bB}$ & $25.8 \mathrm{aA}$ \\
\hline & $10-20$ & $4.8 \mathrm{bB}$ & $12.4 \mathrm{bA}$ \\
\hline & CV $\%$ & \multicolumn{2}{|c|}{7.20} \\
\hline
\end{tabular}

(1) Mean values with the same lowercase letter in a column and same capital letter in the depth layer are not significantly different (Tukey test) at 0.05 probability level 
is less than the $200 \mathrm{~kg}$ of $\mathrm{P}_{2} \mathrm{O}_{5}$ ha $^{-1}$ applied. Moreover, the total $\mathrm{P}$ level in the full grown leaves of vines throughout most of the years was interpreted as normal (0.12 to $0.40 \%$ ) (CQFS, 2004) and therefore, $\mathrm{P}$ application is not recommended, however, vineyards received over the years the addition of $60 \mathrm{~kg}$ of $\mathrm{P}_{2} \mathrm{O}_{5}$ $\mathrm{ha}^{-1}$. Thus, it appears that the amount of $\mathrm{P}$ applied via correction and maintenance fertilization is beyond the need of the soil and the vines, and can be one explanation for the high levels of $\mathrm{Pi}_{\mathrm{RTA}}$ and $\mathrm{Pi}_{\text {bic }}$ in the vineyard soil compared to the native forest soil. Added to this, the data on $\mathrm{Pi}_{\mathrm{RTA}}$ and $\mathrm{Pi}_{\text {bic }}$ in the soil agrees with those obtained in other studies (Gatiboni et al., 2007; Santos et al., 2008; Tokura et al., 2011), that using the technique of chemical fractionation of $\mathrm{P}$, there are reports that the levels of these two fractions of the nutrient in the soil increase with the applied dose of soluble phosphate fertilizers.

Also worth mentioning that Schmitt (2012), which possibly is, so far, one of the few studies found in southern Brazil on P fractions in vineyard soils, reports that in soil profiles that are sandy in texture, with low levels of organic matter and iron oxides, in vineyards of the Campanha Gaúcha region of RS, as well as in the southern region of Santa Catarina state, of ages and $\mathrm{P}_{2} \mathrm{O}_{5}$ amounts applied in the correction and maintenance fertilization, less than the additions performed on the vineyard of this study, that the levels of $\mathrm{Pi}_{\mathrm{RTA}}$ in most layers were greater than $40 \mathrm{mg} \mathrm{dm}^{-3}$. These values are interpreted as very high (CQFS, 2004), increasing environmental pollution, but is also superior to the amounts recorded in this study. This can explain, in part, the greater amount of clay and iron oxide in the soil of this study (Table 1) which was at least five times greater than the amounts reported by Schmitt (2012), and can reduce the amount of $\mathrm{P}$ extracted with anion exchange resin, since there is a strong energy between the oxygen of the phosphate and the cation of the $\mathrm{Fe}-\mathrm{OH}$ groups of the surface oxides (Barrow et al., 1998). Added to this, one should state that the topography of the vineyard in this study is wavy, which may have potentiated, even though there is waste disposal of plant species cover on the soil surface, the transfer of soluble $\mathrm{P}$ in the run off solution or adsorbed the particles suspended in the solution. With all this, it can be verified that the $\mathrm{P}$ applied on the soil classified as Humic Cambisol soil cultivated with vineyards, in greater quantity over the years, compared to a soil with sandy surface texture, such as the Ultisol cultivated with vineyards (Schmitt, 2012), increments less soil P levels accessed by anion exchange resin. Therefore, it can reduce the risk of transfer of the element via solution run off on the soil surface and/or even by percolation, which is desirable, but also believed there is less availability of nutrients for plants, including vines or even plant species cover normally found in the rows of the vineyards, which is not desirable.

In the native forest and vineyard soil, the highest levels of $\mathrm{Po}_{\text {bic }}$ were found in the superficial layer of the soil, up to $10 \mathrm{~cm}$ (Table 2). However, in all layers evaluated, the highest levels of $\mathrm{Po}_{\text {bic }}$ were found in the vineyard soil. These higher levels may be partly attributed to deposition over the years, with subsequent decomposition of plant residues derived from the aerial part of plant species cover that co-inhabited the vineyard, as well as pruned branches, senescent leaves of grapevines and senescent roots, of both plant species cover crops and vines (Brunetto et al., 2011), which can contribute to P cycling.

The inorganic $\mathrm{P}$ fractions extracted with $\mathrm{NaOH} 0.1 \mathrm{~mol} \mathrm{~L}^{-1}$ $\left(\mathrm{Pi}_{\text {hid }}\right)$ and $\mathrm{NaOH} 0.5 \mathrm{~mol} \mathrm{~L}^{-1}\left(\mathrm{Pi}_{\text {hido5 }}\right)$ represent the inorganic $\mathrm{P}$ connected to oxides and silicate clays with intermediate binding energy. Whereas the organic phosphorus extracted with $\mathrm{NaOH}$ $0.1 \mathrm{~mol} \mathrm{~L}^{-1}\left(\mathrm{Po}_{\text {hid }}\right)$ and $0.5 \mathrm{~mol} \mathrm{~L}^{-1}\left(\mathrm{Po}_{\text {hid05 }}\right)$ represents the medium and low labile organic $\mathrm{P}$, respectively (Cross \& Schlesinger, 1995) (Table 3). The highest levels of $\mathrm{Pi}_{\text {hid }}$ in native forest soil were observed in the $0-5 \mathrm{~cm}$ layer, but in the vineyard soil, the highest levels were found up to the depth of $10 \mathrm{~cm}$. The highest levels of $\mathrm{Pi}_{\text {hid }}$ and $\mathrm{Pi}_{\text {hid05 }}$ in all layers evaluated were found in the vineyard soil, which can be attributed in part to the historical application of phosphate fertilizers in the correction and maintenance fertilization, which agree with the data obtained by Basamba et al. (2006), according to these authors applying sources of soluble phosphate fertilizers in soil cultivated with corn monoculture the succession corn-soybean also detected a $\mathrm{Pi}_{\text {hid }}$ increment in the $0-10 \mathrm{~cm}$. However, normally in soils without the application of phosphate fertilizers, as in the native forest soil of the present study, the $\mathrm{Pi}$ fraction determined by $\mathrm{NaOH}$ represents considerable levels of P, especially in soils with higher levels of Fe oxides (Nwoke et al., 2003), which is the case in this study (Table 1).

The highest levels of $\mathrm{Po}_{\text {hid }}$ soil of native forest areas were found in the 5-10 and $10-20 \mathrm{~cm}$ layers, but in the vineyard soil, the highest levels were found in the $0-5 \mathrm{~cm}$ layer (Table 3). However, higher levels of $\mathrm{Po}_{\text {hid }}$ in all soil layers were found in the vineyard soil. This data agrees with those obtained by López et al. (2006), that in a Entisol cultivated with citrus and

Table 3. Inorganic and organic $\mathrm{P}$ extracted with $\mathrm{NaOH}$ $0.1 \mathrm{~mol} \mathrm{~L}^{-1}\left(\mathrm{Pi}_{\text {hid05 }}\right.$ and $\left.\mathrm{Po}_{\text {hid05 }}\right)$, and $\mathrm{NaOH} 0.5 \mathrm{~mol} \mathrm{~L}^{-1}$ $\left(\mathrm{Pi}_{\text {hid05 }}\right.$ and $\left.\mathrm{Po}_{\text {hid05 }}\right)$ fractions in Humic Cambisol in a Forest native site near the vineyard with 33 years of age in three depth layer

\begin{tabular}{|c|c|c|c|}
\hline \multirow{2}{*}{ P fraction } & \multirow{2}{*}{$\begin{array}{c}\text { Depth layer } \\
\text { cm }\end{array}$} & Forest native & Vineyard \\
\hline & & \multicolumn{2}{|c|}{$\mathrm{mg} \mathrm{kg}^{-1}$} \\
\hline \multirow{4}{*}{$\mathrm{Pi}_{\text {hid }}$} & $0-5$ & $95.0 \mathrm{aB}^{(1)}$ & $191.4 \mathrm{aA}$ \\
\hline & $5-10$ & $35.5 \mathrm{bB}$ & $190.0 \mathrm{aA}$ \\
\hline & $10-20$ & $27.6 \mathrm{bB}$ & 81.7 bA \\
\hline & CV \% & \multicolumn{2}{|c|}{2.60} \\
\hline \multirow{4}{*}{$\mathrm{P}_{\text {hid }}$} & $0-5$ & $21.9 \mathrm{bB}$ & $117.3 \mathrm{aA}$ \\
\hline & $5-10$ & $45.2 \mathrm{aB}$ & 84.9 bA \\
\hline & $10-20$ & $50.9 \mathrm{aB}$ & $77.7 \mathrm{bA}$ \\
\hline & CV \% & \multicolumn{2}{|c|}{7.64} \\
\hline \multirow{4}{*}{$\mathrm{Pi}_{\text {hid05 }}$} & $0-5$ & $70.6 \mathrm{aB}$ & $106.4 \mathrm{aA}$ \\
\hline & $5-10$ & $60.8 \mathrm{aB}$ & $96.3 \mathrm{aA}$ \\
\hline & $10-20$ & $40.4 \mathrm{bB}$ & $54.6 \mathrm{bA}$ \\
\hline & CV \% & \multicolumn{2}{|c|}{10.10} \\
\hline \multirow{4}{*}{$\mathrm{P}_{\text {hid05 }}$} & $0-5$ & $58.3 \mathrm{ABB}$ & $142.6 \mathrm{abA}$ \\
\hline & $5-10$ & $68.2 \mathrm{aB}$ & $147.9 \mathrm{aA}$ \\
\hline & $10-20$ & $38.4 \mathrm{bB}$ & $117.2 \mathrm{bA}$ \\
\hline & CV $\%$ & \multicolumn{2}{|c|}{13.36} \\
\hline
\end{tabular}

(1) Mean values with the same lowercase letter in a column and same capital letter in the depth layer are not significantly different (Tukey test) at 0.05 probability level 
a historical application of soluble phosphate fertilizers over the period of 7 years, they observed an accumulation of $\mathrm{Po}_{\text {hid }}$ in the soil compared to the soil of reference, with no history of cultivation or phosphorus fertilization. These authors attribute the $\mathrm{Po}_{\text {hid }}$ accumulation in the soil, as a greater use of phosphate fertilizers by plants and microorganisms, turning into organic $\mathrm{P}$. The $\mathrm{Po}_{\text {hido5 }}$ levels accumulated until the $10 \mathrm{~cm}$ layer respectively in the area of native forest and vineyard soil. As in other fractions, among them the $\mathrm{Po}_{\text {bic }}$ and the $\mathrm{Po}_{\text {hid }}$, the $\mathrm{Po}_{\text {hido5 }}$ levels were higher in the vineyard soil in relation to the native forest soil.

The level of inorganic $\mathrm{P}$ extracted with $\mathrm{HCl} 1 \mathrm{~mol} \mathrm{~L}^{-1}\left(\mathrm{Pi}_{\mathrm{HCl}}\right)$, according to Cross \& Schlesinger (1995), extracts preferably the fractions linked to calcium. The highest levels of $\mathrm{Pi}_{\mathrm{HCl}}$ were found in the superficial layer of soil $(0-5 \mathrm{~cm})$ in the native forest and vineyard area (Table 4). But in all layers the highest levels of $\mathrm{Pi}_{\mathrm{HCl}}$ were found in the vineyard soil which has a history of application of phosphate fertilizers in correction and maintenance fertilization. It is worth mentioning that the levels of $\mathrm{Pi}_{\mathrm{HCl}}$ were much higher than those found in the native forest soil. Rheinheimer \& Anghinoni (2001) comment that in soils under no-tillage system in southern Brazil there may occur the increment in calcium-P fractions in the soil due to the long-term application of phosphate fertilizers on the soil surface layer. Thus, it is likely that a similar phenomenon has occurred in the vineyard soil, because in the maintenance fertilization of vines over the years, the P fertilizer was applied on the soil surface without incorporation and in doses higher than the demand of the crop $\left(60 \mathrm{~kg} \mathrm{ha}^{-1}\right.$ of $\mathrm{P}_{2} \mathrm{O}_{5}$ in correction fertilization and 200 $\mathrm{kg} \mathrm{ha}^{-1}$ of $\mathrm{P}_{2} \mathrm{O}_{5}$ in maintenance fertilization) that were probably defined without considering the technical criteria established, as for example, the results of the analysis of the soil, tissue and expected production. Added to this, $\mathrm{P}$ export through grape bunches is normally low and, due to all this, it is expected that the increase of soil $\mathrm{P}$ in various fractions, as well as allowing to maintain part of the $\mathrm{P}$ linked to calcium, derived from the phosphorus itself (such as apatite, dicalcium and octacalcium phosphate) or lime applications before planting the vineyard, to correct soil acidity.

Table 4. Inorganic $\mathrm{P}$ extracted by $\mathrm{HCl} 1 \mathrm{~mol} \mathrm{~L}^{-1}\left(\mathrm{Pi}_{\mathrm{HCl}}\right)$ and residual $\mathrm{P}\left(_{\text {residual }}\right.$ P) fractions in Humic Cambisol in a Forest native site near the vineyard with 33 years of age in three depth layer

\begin{tabular}{|c|c|c|c|}
\hline \multirow{2}{*}{$P$ fraction } & \multirow{2}{*}{$\begin{array}{c}\text { Depth layer } \\
\text { cm }\end{array}$} & Forest native & Vineyard \\
\hline & & \multicolumn{2}{|c|}{$\mathrm{mg} \mathrm{kg}^{-1}$} \\
\hline \multirow{4}{*}{$\mathrm{Pi}_{\mathrm{HCl}}$} & $0-5$ & $12.2 \mathrm{aB}^{(1)}$ & $127.8 \mathrm{aA}$ \\
\hline & $5-10$ & $7.6 \mathrm{bB}$ & $114.2 \mathrm{bA}$ \\
\hline & $10-20$ & $5.6 \mathrm{bB}$ & $15.7 \mathrm{cA}$ \\
\hline & CV, \% & \multicolumn{2}{|c|}{3.62} \\
\hline \multirow{4}{*}{ Residual P } & $0-5$ & $357.6 \mathrm{aB}$ & $405.3 \mathrm{aA}$ \\
\hline & $5-10$ & $333.5 \mathrm{aB}$ & $402.0 \mathrm{aA}$ \\
\hline & $10-20$ & $331.9 \mathrm{aA}$ & $357.9 \mathrm{aA}$ \\
\hline & $\mathrm{CV}, \%$ & \multicolumn{2}{|c|}{6.54} \\
\hline
\end{tabular}

(1) Mean values with the same lowercase letter in a column and same capital letter in the depth layer are not significantly different (Tukey test, $p<0.05$ )
The level of $\mathrm{P}$ extracted with $\mathrm{H}_{2} \mathrm{SO}_{4}+\mathrm{H}_{2} \mathrm{O}_{2}+\mathrm{MgCl}_{2}$ (residual $_{\text {a }}$ $\mathrm{P})$, which is a recalcitrant $\mathrm{P}$ fraction of difficult access through selective chemical extractants in soil and which can contribute to plant nutrition although only in situations of extreme lack of soil nutrient (Gatiboni et al., 2007), was similar in depth both in the native forest and the vineyard soil (Table 5). However, the highest levels of ${ }_{\text {residual }} \mathrm{P}$ in all soil layers were found in the vineyard soil, except for the $10-20 \mathrm{~cm}$ layer, where the levels were equal in both the native forest and the vineyard soil. These high levels of ${ }_{\text {residual }} P$ in the soil area of the native forest, but especially in the vineyard, may be due to clay and iron oxides extracted with citrate-bicarbonate-dithionite and ammonium oxalate (Table 1). This data also agrees with those obtained by Santos et al. (2008), in a Typic Hapludalf soil of clayey texture, and historical application of $180 \mathrm{~kg}$ of $\mathrm{P}_{2} \mathrm{O}_{5}$ ha $^{-1}$ during three years of corn cultivation, they found prevalence of residual $\mathrm{P}$ fraction in $0-20 \mathrm{~cm}$.

The geochemical $\mathrm{P}$ obtained by the sum of fractions $\left(\mathrm{Pi}_{\text {RTA }}\right.$ $\left.+\mathrm{Pi}_{\text {bic }}+\mathrm{Pi}_{\text {hid }}+\mathrm{Pi}_{\text {hid05 }}+\mathrm{Pi}_{\mathrm{HCl}}+{ }_{\text {residual }} \mathrm{P}\right)$ was higher in the $0-5 \mathrm{~cm}$ layer in the native forest soil and up to $10 \mathrm{~cm}$ in the vineyard soil (Table 5). However, in all layers, the highest levels were found in the vineyard soil layers. The biological $\mathrm{P}$ levels $\left(\mathrm{Po}_{\mathrm{bic}}\right.$ $+\mathrm{Po}_{\text {hid }}+\mathrm{Po}_{\text {hid05 }}$ ) of the native forest soil were higher in the 5-10 and $10-20 \mathrm{~cm}$ layer. Whereas in the vineyard soil, the highest levels were found up to a depth of $10 \mathrm{~cm}$. However, in all layers, the highest values of biological $\mathrm{P}$ were found in the vineyard soil. These higher levels of biological $P$ in the vineyard soil, can be explained in part due to the fact that most of the soil $\mathrm{P}$ was found predominantly accumulated in inorganic fractions and, so, there is less utilization of $\mathrm{P}$ in organic fractions by plants (Gatiboni et al., 2008).

The highest levels of total $P$, which represents the sum of all fractions of the element were observed in the $0-5 \mathrm{~cm}$ layer of the native forest soil and up to a depth of $10 \mathrm{~cm}$ in the vineyard soil (Table 5). But in all layers the highest levels were found in the vineyard soil, compared to the native forest soil, in agreement with the data obtained for geochemical and biological P. The

Table 5. Geochemical and biological P Pools, total $P$ in in Humic Cambisol in a Forest native near the vineyard with 33 years of age in three depth layer

\begin{tabular}{|c|c|c|c|}
\hline \multirow{2}{*}{$P$ fraction } & \multirow{2}{*}{$\begin{array}{c}\text { Depth layer } \\
\text { cm }\end{array}$} & Forest native & Vineyard \\
\hline & & \multicolumn{2}{|c|}{$\mathrm{mg} \mathrm{kg}^{-1}$} \\
\hline \multirow{4}{*}{ Geochemical P } & $0-5$ & $554.6 \mathrm{aB}^{(1)}$ & $782.8 \mathrm{aA}$ \\
\hline & $5-10$ & $443.9 \mathrm{bB}$ & $761.7 \mathrm{aA}$ \\
\hline & $10-20$ & $407.3 \mathrm{bB}$ & 519.7 bA \\
\hline & CV \% & \multicolumn{2}{|c|}{4.28} \\
\hline \multirow{4}{*}{ Biological P } & $0-5$ & $85.3 \mathrm{bB}$ & $288.2 \mathrm{aA}$ \\
\hline & $5-10$ & $123.4 \mathrm{aB}$ & $258.6 \mathrm{aA}$ \\
\hline & $10-20$ & $94.2 \mathrm{abB}$ & $207.3 \mathrm{bA}$ \\
\hline & CV \% & \multicolumn{2}{|c|}{9.64} \\
\hline \multirow{4}{*}{ Total P } & $0-5$ & $652.0 \mathrm{aB}$ & $1198.8 \mathrm{aA}$ \\
\hline & $5-10$ & $574.8 \mathrm{bB}$ & $1134.5 \mathrm{aA}$ \\
\hline & $10-20$ & $507.1 \mathrm{bB}$ & $742.7 \mathrm{bA}$ \\
\hline & CV \% & \multicolumn{2}{|c|}{4.00} \\
\hline
\end{tabular}

(1) Mean values with the same lowercase letter in a column and same capital letter in the depth layer are not significantly different (Tukey test at 0.05 probability) 
total P level observed in the vineyard soil in the 0-5 and 5-10 $\mathrm{cm}$ layers was approximately twice the level found in the area of native forest soil with no history of cultivation, which is attributed to correction and maintenance fertilization.

\section{Conclusions}

1. The excessive application of phosphorus fertilizers in correction and maintenance fertilization during 33 years in the vineyard soil increased the level of organic and inorganic phosphorus up to the $20 \mathrm{~cm}$ layer in all phosphorus fractions.

2. The highest levels of phosphorus in the vineyard soil were found mainly in labile fractions extracted with anion exchange resin $\left(\mathrm{Pi}_{\mathrm{RTA}}\right)$ and $\mathrm{NaHCO}_{3}\left(\mathrm{Pi}_{\text {bic }}\right.$ and $\left.\mathrm{Po}_{\text {bic }}\right)$, which can increase high nutrient availability to plants, but also indicates the potentiation of solution transfer from soil to surface run-off or percolated through the soil profile, which represents greater potential for contamination of surface and subsurface waters.

\section{ACKNOWLedgments}

The National Council for Scientific and Technological Development (CNPq) for financial support (Process No. 471671/2010-0). The Coordination of Improvement of Higher Education Personnel (CAPES), for granting master's scholarship to the first author.

\section{Literature Cited}

Barrow, N. J.; Bolland, M. D. A.; Allen, D. G. Effect of addition of superphosphate on sorption of phosphate. Australian Journal Soil Research, v.36, p.359-372, 1998.

Basamba, T. A.; Barrios, E.; Amézquita, E.; Rao, I. M.; Singh, B. R. Tillage effects on maize yield in a Colombian savanna oxisol: Soil organic matter and P fractions. Soil \& Tillage Research, v.91, p.131-142, 2006.

Boschetti, N.G.; Quintero, C.E.; Giuffre, L. Phosphorus fractions of soils under Lotus corniculatus as affected different phosphorus fertilizers. Biology and Fertility of Soils, v.45, p.379-384, 2009.

Brunetto, G.; Ventura, M.; Scandellari, F.; Ceretta, C. A.; Kaminski, J.;Melo, G. W. B.; Tagliavini, M. Nutrients release during the decomposition of mowed perennial ryegrass and white clover and its contribution to nitrogen nutrition of grapevine. Nutrient Cycling in Agroecosystems, v.90, p.299-308, 2011.

Chien, S. H.; Prochnow, L. I.; Tu, S.; Snyder, C. S. Agronomic and environmental aspects of phosphate fertilizers varying in source and solubility: an update review. Nutrient Cycling in Agroecosystems, v.89, p.229-255, 2011.

Condron, L. M.; Goh, K. M.; Newman, R. H. Nature and distribution of soil phosphorus as revealed by a sequential extraction method followed by $31 \mathrm{P}$ nuclear magnetic resonance analysis. Journal Soil Science, v.36, p.199-207, 1985.
CQFS - Comissão de Química e Fertilidade do Solo - RS/SC. Manual de adubação e de calagem para os Estados do Rio Grande do Sul e Santa Catarina. 10.ed. Porto Alegre: SBCS/ NRS, 2004. 400p.

Cross, A. F.; Schlesinger, W. H. A literature review and evaluation of the Hedley fractionation: Aplications to the biogeochemical cycle of soil phosphorus in natural ecosystems. Geoderma, v.64, p.197-214, 1995.

Dick, W. A.; Tabatabai, M. A. determination of orthophosphate in aqueous solutions containing labile organic and inorganic phosphorus compounds. Journal of Environmental Quality, v.6, p.82-85, 1977.

EMBRAPA - Empresa Brasileira de Pesquisa Agropecuária. Manual de métodos de análise de solos. , Rio de Janeiro: Embrapa Solos, 1997. 212p.

EMBRAPA - Empresa Brasileira de Pesquisa Agropecuária. Manual de análises químicas de solos, plantas e fertilizantes. Rio de Janeiro: Embrapa CNPS, 1999. 372p.

Gatiboni, L. C., Brunetto, G.; Kaminski, J.; Rheinheimer, D. S.; Ceretta, C. A.; Basso, C. J. Formas de fósforo no solo após sucessivas adições de dejeto líquido de suínos em pastagem natural. Revista Brasileira de Ciência do Solo, v.32, p.17531761, 2008.

Gatiboni, L. C.; Kaminski, J.; Rheinheimer, D. S.; Flores, J. P. C. Biodisponibilidade de formas de fósforo acumuladas em solo sob sistema plantio direto. Revista Brasileira de Ciência do Solo, v.31, p.691-669, 2007.

Hedley, M. J.; Stewart, J. W. B.; Chauhan, B. S. Changes in inorganic and organic soil phosphorus fractions induced by cultivation practices and by laboratory incubations. Soil Science Society of America Journal, v.46, p.970-976, 1982.

IBGE - Instituto Brasileiro de Geografia e Estatística. Levantamento sistemático da produção agrícola pesquisa mensal de previsão e acompanhamento das safras agrícolas no ano civil. http://www.ibge.com.br/ 8 Nov. 2011.

Korboulewsky, N.; Dupoyet, S.; Bonin, G. Environmental risks of applying sewage sludge compost to vineyards: Carbon, heavy metals, nitrogen and phosphorus accumulation. Journal Environmental Quality, v.31, p.1522-1527, 2002.

López, C. F.;Mendoza, R.; Vazquez, S. Fracciones de fósforo em suelos de corrientes con producción citrícola, arrocera y pastoril. Ciencia del Suelo, v.24, p.161-168, 2006.

Mehra, O. P.; Jackson, M. L. Iron oxide removal from soils by a dithionite-citrate system buffered with sodium bicarbonate. Clays \& Clay Minerals, v.7, p.317-327, 1960.

Murphy, J.; Riley, J. P. A modified single solution method for the determination of phosphate in natural waters. Analytica Chimica Acta, v.27, p.31-36, 1962.

Nwoke, O.C.; Vanlauwe, B.; Diels, J.; Sanginga, N.; Osonubi, O.; Merckx, R. Assessment of labile phosphorus fractions and adsorption characteristics in relation to soil properties of West African Savanna soils. Agriculture Ecosystems \& Environment, v.100, p.285-294, 2003. 
Oliveira, M. F. M.; Favaretto, N.; Roloff, G.; Fernandes, C. V. S. Estimativa do potencial de perda de fósforo através da metodologia "PIndex". Revista Brasileira de Engenharia Agrícola e Ambiental, v.14, p.267-273, 2010.

Pizzeghello, D.; Berti, A.; Nardi, S.; Morari, F. Phosphorus forms and $\mathrm{P}$-sorption properties in three alkaline soils after longterm mineral and manure applications in north-eastern Italy. Agriculture, Ecosystems and Environment, v.141, p.58-66, 2011.

Ramos, M. C.; Martínez-casasnovas, J. A. Nutrient losses by runoff in vineyards of the Mediterranean Alt Penede's region (NE Spain). Agriculture Ecosystems \& Environment, v.113, p.356-363, 2006.

Rheinheimer, D. S. Anghinoni, I. Distribuição do fósforo inorgânico em sistemas de manejo de solo. Pesquisa Agropecuária Brasileira, v.36, p.151-160, 2001.
Santos, J. Z. L.; Furtini, A. E. N.; Resende, Á. V.; Curi, N.; Carneiro, L. F.; Costa, S. E. V. G. A. Frações de fósforo em solo adubado com fosfatos em diferentes modos de aplicação e cultivado com milho. Revista Brasileira de Ciência do Solo, v.32, p.705-714, 2008.

SAS Institute Inc ${ }^{\circledast}$. SAS Ver. 9.1.3. Cary: SAS Institute, 2003.

Schmitt, D. E. Acúmulo de fósforo e potencial contaminante em solos cultivados com videira. Florianópolis: UFSC, 2012. 77p. Dissertação Mestrado

Soil Survey Staff. Soil taxonomy. 2.ed. Washington: United States Departament of Agriculture, 1999. 869p.

Tedesco, M. J.; Gianello, C.; Bissani, C.; Bohnen, H.; Volkweiss, S. J. Análise de solo, plantas e outros materiais. Porto Alegre: UFRS, 1995.174p.

Tokura, A. M.; Furtini neto, A. E.; Carneiro, F. C.; Curi, N.; Lopes santos, J. Z.; Alovisi, A. A. Dinâmica das formas de fósforo em solos de textura e mineralogia contrastantes cultivados com arroz. Acta Scientiarum Agronomy, v.33, p.171-170, 2011. 